\title{
Work with visual display units in pregnancy
}

\author{
A D MCDONALD, J C MCDONALD, B ARMSTRONG, N CHERRY, A D NOLIN, \\ D ROBERT
}

From the Institut de Recherche en-Santé et en Sécurité du Travail du Québec, Montreal, Québec, H3A 3C2, Canada

ABSTRACT Data from the Montreal survey on occupational factors in pregnancy were used to test the hypothesis that visual display units (VDUs) constitute a hazard to reproduction. Use of a VDU was recorded in 4712 current and 2164 previous pregnancies of women in full time employment at time of conception. After allowance for seven confounding variables, the risk of spontaneous abortion in current pregnancies relative to all working women was $1 \cdot 19(90 \% \mathrm{CI} 1 \cdot 09-1 \cdot 30)$ and in previous pregnancies, 0.97 . In an analysis by occupational title, in which 60 occupational groups were aggregated into eight categories according to use of VDUs, the relative risk for spontaneous abortion was $1.06(90 \% \mathrm{CI} 0.8-1.4)$ in current pregnancies and $1.01(90 \% \mathrm{CI} 0.7-1.3)$ in previous pregnancies. This suggests that the small excess of spontaneous abortions among individual women reporting the use of VDUs in current pregnancies may have been due to recall bias. Relative risks for stillbirth, preterm birth, and low birth weight all had $90 \%$ confidence limits which included unity. In an analysis of congenital defects the number of pregnancies was increased to include women who worked 15 or more hours a week. In all but one of nine groups of congenital defect examined confidence limits for the relative risk included unity in both current and previous pregnancies. The relative risks for the renal urinary group of defects were raised in both current $(1 \cdot 84,90 \%$ CI $1 \cdot 07-3 \cdot 15)$ and previous pregnancies $(1 \cdot 66,90 \% \mathrm{CI} 0 \cdot 82-3 \cdot 25)$. There being no prior reason to suspect a causal link with this type of defect, interpretation remains open to question.

In North America, 1978-80, clusters of spontaneous abortion or birth defect in women who had used visual display units (VDUs) in pregnancy received wide publicity. ${ }^{2}$ The estimated number of pregnant women who worked with VDUs was such that the reported clusters could have occurred by 'chance. ${ }^{1-5}$ Nevertheless, suspicion once aroused was not easily allayed.

Measurement of emissions from VDUs in use at that time showed that $x$ ray, ultraviolet, visible, infrared, and radiofrequency radiations were considerably below current threshold limit values. ${ }^{6}$ Two types of radiation-ionising and microwave-are known to be associated with biological effects. ${ }^{7}$ The level of ionising radiation emitted by VDUs has rarely been found to be above background level' ${ }^{\prime}$ and VDUs do not emit microwaves.' Radiofrequency waves of high, low, and very low frequency of varying degrees of intensity are detectable near VDUs; they are also found close to other commonly used electrical equip-

Accepted 14 August 1987 ment such as television sets, electric typewriters, and some kitchen appliances. ${ }^{1}$ These emissions are generally considered to be negligible but, because a possible biological effect of very low frequency waves had not been specifically investigated, attempts have been made in the past few years to do so.

Experimental studies with embryos of hens and small mammals have been recently reviewed. ${ }^{48}$ Exposure of eggs to electromagnetic fields was reported to have affected chick embryogenesis.' These experiments, repeated with some technical improvements, gave negative results. ${ }^{10}$ In a second study the results were also negative but in a third some increase in abnormalities was found. " In an experiment in which pregnant mice were exposed to a pulsed magnetic field of sawtooth variety a small excess of external malformations was observed. ${ }^{12}$ In none of these experiments was the type of radiation the same as that found with VDUs. Whatever the experimental findings, however, it cannot be assumed that the human fetus would be affected in the same way as other species. Only epidemiological studies can 
determine whether the use of VDUs in pregnancy has an adverse effect in human reproduction. Those reported to date have not supported the hypothesis that there is such a risk..$^{13-15}$

\section{Montreal survey}

In a study of occupational factors in pregnancy interviews were carried out for a two year period (11 May 1982-10 May 1984) in 11 maternity units at which some $90 \%$ of Montreal births take place, with 51885 women who had just delivered and 4127 who were treated for a spontaneous abortion during the same period. The women were questioned on occupational, personal, and social factors in their current and all previous pregnancies-104 649 in all. The methods used have been described and the frequency of four main adverse outcomes (spontaneous abortion, stillbirth, congenital defect, and low birth weight) reported for 60 occupational groups in six main occupational sectors. ${ }^{16}$ Work conditions and chemical exposures have been reported for fetal death in previous pregnancies, ${ }^{17}$ for congenital defects in current and previous pregnancies, ${ }^{18}$ and work conditions for preterm births and low birth weight in current pregnancies. $^{19}$

The present report addresses the question of whether the use of VDUs affected any of these four adverse outcomes. Before the complete data set was ready for analysis in March 1986 the relation of the use of VDUs to spontaneous abortion and congenital defect was studied in those occupations in which at least $5 \%$ of women reported using a VDU for 15 or more hours a week. In a preliminary analysis of some 17000 current and previous pregnancies, no difference was detected in VDU users compared with non-users in the rates of different types of congenital defect nor in the risk of spontaneous abortion in previous pregnancies. ${ }^{2021}$ Spontaneous abortions in current pregnancies, after which women were interviewed, were associated with the use of VDUs after allowance by means of logistic regression for seven confounding variables. A grouped analysis of 42 occupations, however, showed that ratios of abortions observed to those expected, after allowing for confounding variables, did not differ in occupations with substantial use of VDUs compared with those in which VDUs were used little or not at all. On balance, we considered that the positive finding for spontaneous abortion in current pregnancies was probably due to recall bias. Consistent with this hypothesis was a depressed $\mathrm{O} / \mathrm{E}$ ratio for abortions in non-users for which we believe the most likely explanation was underreporting, after a normal term delivery, of VDU use at the beginning of pregnancy and overreporting immediately after a spontaneous abortion.

\section{Methods}

INTER VIEWS

Women were seen by nurse interviewers before they left hospital but if this was not possible, which happened more frequently after a spontaneous abortion or stillbirth than after delivery of a liveborn baby, an interview was sought by telephone. Only about half the spontaneous abortions in Montreal are treated in hospital; in about three quarters of these the women were successfully interviewed. Only about a third of stillbirths were interviewed, however, mainly because women were distressed by the event. On the other hand, for previous pregnancies fetal deaths were probably reported fully.

The proportion of abortions in previous pregnancies was inflated because women were interviewed at the end of a subsequent pregnancy. As family size today tends to be deliberately chosen, women who have achieved the desired number of successful pregnancies do not seek a further pregnancy whereas those who have had an abortion become pregnant again. The proportion of abortions in previous pregnancies was strongly affected by the proximity of the date of conception to that of the current pregnancy. This created a problem in the analysis as the use of VDUs was rising quite steeply, at some $5 \%$ a year. This would create a spurious association between the use of VDUs and abortions unless account was taken of date of conception (see statistical analysis).

Care was taken to exclude induced abortions, which are legal in Quebec. In the present report the term abortion refers to abortions of less than 28 weeks gestation believed to be spontaneous. Congenital defects were ascertained for current pregnancies by review of the medical record by a physician or a nurse other than the one who conducted the interview. For previous pregnancies information on defects was obtained from the mother but, for both current and previous pregnancies, it was supplemented in doubtful cases by further inquiries from physicians and hospitals.

Information on employment was gathered at the interview with the woman at the end of the current pregnancy. One of the questions on employment was whether the job required the regular use of a VDU and, if so, for how many hours a week. The nurse was asked to record this and other work requirements at the time of the first missed menstrual period.

The pregnancies used in this study were defined somewhat differently according to outcome. Pregnancies of women who were employed for 30 or more hours a week at the start of pregnancy were analysed for abortion and prematurity whereas for stillbirth, pregnancies of women employed 30 or more hours for at least two weeks at any time in pregnancy were 
studied because this definition had been used in a previous analysis. As in only $5.6 \%$ of these pregnancies was the woman not employed at the start, for the sake of economy we kept the same definition. Because of the infrequency of particular types of congenital defect, women employed 15 to 30 hours a week at the start of pregnancy were included; this added $15 \%$ to the population. Current and previous pregnancies were analysed for all outcomes except prematurity for which current pregnancies only were used because duration of gestation was obtained from the medical record; for previous pregnancies recall of duration of gestation was not considered sufficiently accurate.

\section{STATISTICAL ANALYSIS}

The main statistical method used was to enter confounding variables - seven in the case of abortion and stillbirth (age, gravidity, previous miscarriage, ethnic group, educational level, smoking, and alcohol consumption) - into a logistic regression analysis and to calculate the probability of abortion and stillbirth from the regression coefficients. ${ }^{16}$ Expected numbers (E) of these outcomes in specific groups were calculated from the probabilities and compared with the observed numbers $(\mathrm{O})$ by a ratio $(\mathrm{O} / \mathrm{E})$. This $\mathrm{O} / \mathrm{E}$ ratio approximates to the risk of adverse outcome in the group relative to that in other working women when the groups of interest comprise a small proportion of the total sample. Ninety per cent confidence intervals for $\mathrm{O} / \mathrm{E}$ ratios were calculated on the assumption that the distribution of observed adverse outcomes would be approximately Poisson. Tests for trend in $\mathrm{O} / \mathrm{E}$ ratios were made by Poisson regression techniques, using the GLIM computer package. ${ }^{22}$
Individual analyses

Individual analyses, as described above, were undertaken in three groups according to the number of hours a week of reported VDU use: none, less than 15 hours, and 15 hours or more. To correct for the possible confounding effect of type of occupation $\mathrm{O} / \mathrm{E}$ ratios were calculated within three broad occupational sectors: managerial (including computer programmers), clerical, and other. The latter group comprised the other four sectors in which the use of VDUs was uncommon-health, sales, services, and manufacturing.

Current and previous pregnancies were analysed separately because, for reasons given under Methods, abortions and stillbirths were much less frequently interviewed in current than previous pregnancies: abortions: $7 \cdot 9 \%$ and $22 \cdot 4 \%$, stillbirths: $0.37 \%$ and $1.07 \%$. In the analysis reported below a correction for date of conception was applied to $\mathrm{O} / \mathrm{E}$ ratios for previous pregnancies by stratifying groups by year and multiplying by the $\mathrm{O} / \mathrm{E}$ ratio for that stratum among all working women.

\section{Grouped analyses}

Grouped analyses were also undertaken to minimise the effect of recall bias arising from the retrospective nature of this study. The proportion of all women who reported the use of a VDU for 15 or more hours a week was calculated for each of 60 occupational groups. The 60 occupational groups were aggregated into eight categories according to frequency of the use of VDUs and a relation sought with abortion risk, indicated by the $\mathrm{O} / \mathrm{E}$ ratio.

Relative risk associated with the use of VDUs was

Table 1 Ratios of observed $(O)$ to expected $(E)$ abortions by the use of VDUs in managerial, clerical, and remaining occupational sectors* (current and previous pregnancies)

\begin{tabular}{|c|c|c|c|c|c|c|c|c|}
\hline \multirow[b]{2}{*}{ Sectors } & \multirow[b]{2}{*}{ No } & \multicolumn{3}{|c|}{ Current } & \multirow[b]{2}{*}{ No } & \multicolumn{3}{|c|}{ Previoust } \\
\hline & & $O$ & $O / E$ & $(90 \% C I)$ & & $O$ & $O / E$ & $(90 \% C I)$ \\
\hline $\begin{array}{l}\text { Managerial-total: } \\
\text { VDU nil } \\
\text { VDU <15 h/wk } \\
\text { VDU } \geqslant 15 \mathrm{~h} / \mathrm{wk}\end{array}$ & $\begin{array}{r}4558 \\
3677 \\
571 \\
310\end{array}$ & $\begin{array}{r}316 \\
252 \\
41 \\
23\end{array}$ & $\begin{array}{l}0.98 \\
0.96 \\
1 \cdot 11 \\
1.00\end{array}$ & $\begin{array}{l}(0.89-1.08) \\
(0.87-1.07) \\
(0.84-1.42) \\
(0.69-1.42)\end{array}$ & $\begin{array}{r}3818 \\
3422 \\
270 \\
126\end{array}$ & $\begin{array}{r}827 \\
729 \\
66 \\
32\end{array}$ & $\begin{array}{l}1.00 \\
0.99 \\
1.04 \\
0.95\end{array}$ & $\begin{array}{l}(0.94-1.06) \\
(0.93-1.05) \\
(0.84-1.26) \\
(0.64-1.25)\end{array}$ \\
\hline $\begin{array}{l}\text { Clerical-total: } \\
\text { VDU nil } \\
\text { VDU < } 15 \mathrm{~h} / \mathrm{wk} \\
\text { VDU } \geqslant 15 \mathrm{~h} / \mathrm{wk}\end{array}$ & $\begin{array}{rl}10 & 662 \\
7 & 155 \\
1680 \\
1 & 827\end{array}$ & $\begin{array}{l}719 \\
448 \\
125 \\
146\end{array}$ & $\begin{array}{l}1.01 \\
0.92 \\
1.17 \\
1.26\end{array}$ & $\begin{array}{l}(0.95-1.08) \\
(0.85-1.00) \\
(1.00-1 \cdot 34) \\
(1.10-1.44)\end{array}$ & $\begin{array}{r}9500 \\
7853 \\
768 \\
879\end{array}$ & $\begin{array}{r}1959 \\
1578 \\
163 \\
218\end{array}$ & $\begin{array}{l}1.00 \\
1.01 \\
0.92 \\
1.02\end{array}$ & $\begin{array}{l}(0.96-1.04) \\
(0.97-1.05) \\
(0.61-1.04) \\
(0.91-1.14)\end{array}$ \\
\hline $\begin{array}{l}\text { Other*_total: } \\
\text { VDU nil } \\
\text { VDU <15 h/wk } \\
\text { VDU } \geqslant 15 \mathrm{~h} / \mathrm{wk}\end{array}$ & $\begin{array}{l}9394 \\
9071 \\
169 \\
154\end{array}$ & $\begin{array}{r}728 \\
702 \\
11 \\
15\end{array}$ & $\begin{array}{l}0.99 \\
0.99 \\
0.99 \\
1.41\end{array}$ & $\begin{array}{l}(0.94-1.06) \\
(0.93-1.05) \\
(0.55-1.64) \\
(0.87-2.17)\end{array}$ & $\begin{array}{r}9199 \\
9082 \\
70 \\
\\
51\end{array}$ & $\begin{array}{r}2166 \\
2135 \\
19 \\
12\end{array}$ & $\begin{array}{l}1.00 \\
1.01 \\
0 \cdot 86 \\
0.85\end{array}$ & $\begin{array}{l}(0.96-1.04) \\
(0.97-1.05) \\
(0.56-1.26) \\
(0.49-1.38)\end{array}$ \\
\hline $\begin{array}{l}\text { All sectors-total: } \\
\text { VDU nil } \\
\text { VDU }<15 \mathrm{~h} / \mathrm{wk} \\
\text { VDU } \geqslant 15 \mathrm{~h} / \mathrm{wk}\end{array}$ & $\begin{array}{r}24614 \\
19903 \\
2420 \\
2291\end{array}$ & $\begin{array}{r}1763 \\
1402 \\
177 \\
184\end{array}$ & $\begin{array}{l}1 \cdot 00 \\
0.96 \\
1 \cdot 14 \\
1 \cdot 23\end{array}$ & $\begin{array}{l}- \\
(0 \cdot 92-1 \cdot 00) \\
(1.00-1 \cdot 29) \\
(1.09-1 \cdot 38)\end{array}$ & $\begin{array}{rl}22 & 517 \\
20 & 357 \\
1 & 108 \\
1 & 056\end{array}$ & $\begin{array}{r}4887 \\
4472 \\
249 \\
166\end{array}$ & $\begin{array}{l}1.00 \\
1.00 \\
0.95 \\
1.00\end{array}$ & $\begin{array}{l}- \\
(0.98-1.02) \\
(0.85-1.05) \\
(0.88-1.63)\end{array}$ \\
\hline
\end{tabular}

${ }^{*}$ Health, sales, services, and manufacturing sectors.

tCorrected for year of conception. 
Table 2 Ratio of observed $(O)$ to expected $(E)$ abortions in current pregnancies in 60 occupations grouped according to the percentage of pregnancies in which a VDU was used for 15 or more hours a week

\begin{tabular}{|c|c|c|c|c|c|}
\hline \multirow{2}{*}{$\begin{array}{l}\text { Pregnancies } \\
\text { with VDU use } \\
(\geqslant 15 \text { h/wk }) \%\end{array}$} & \multirow{2}{*}{$\begin{array}{l}\text { No of } \\
\text { occupations }\end{array}$} & \multirow{2}{*}{$\begin{array}{l}\text { No of } \\
\text { pregnancies }\end{array}$} & \multicolumn{2}{|c|}{ Abortions } & \multirow[b]{2}{*}{ Ratio $O / E$} \\
\hline & & & $O$ & $E$ & \\
\hline $\begin{array}{l}0 \\
<2 \\
2<5 \\
5<10 \\
10<20 \\
20<40 \\
40<60 \\
\geqslant 60\end{array}$ & $\begin{array}{r}21 \\
10 \\
6 \\
12 \\
5 \\
3 \\
2 \\
1\end{array}$ & $\begin{array}{r}4819 \\
3833 \\
2346 \\
6791 \\
4184 \\
1595 \\
336 \\
802\end{array}$ & $\begin{array}{r}385 \\
283 \\
157 \\
466 \\
358 \\
113 \\
27 \\
57\end{array}$ & $\begin{array}{c}387 \cdot 52 \\
296 \cdot 48 \\
162 \cdot 36 \\
461 \cdot 75 \\
341 \cdot 84 \\
106 \cdot 66 \\
25 \cdot 24 \\
59 \cdot 1\end{array}$ & $\begin{array}{l}0.99 \\
0.95 \\
0.97 \\
1.01 \\
1.05 \\
1.06 \\
1.07 \\
0.96\end{array}$ \\
\hline All & 60 & 24706 & 1846 & 1840.95 & 1.00 \\
\hline
\end{tabular}

estimated from the (Poisson) regression of $\mathrm{O} / \mathrm{E}$ ratios for the 60 occupational groups. This method was essentially as described for analysis of an ecological study. ${ }^{23}$ Because the proportion of women in an occupational group who reported using VDUs depended predominantly on the responses from women who had liveborn children, this approach to assessing risk should be minimally affected by response bias.

For preterm births and children of low birth weight the method of analysis used was as for abortions with the same seven confounding variables plus maternal height. Because of the many different types of congenital defect ${ }^{18}$ and the questionable effect of confounding variables for each of them, no correction was made for confounders in this analysis. Risk of congenital defect in births to women using VDUs, relative to those not doing so, were estimated in the usual way as odds ratios in two by two tables. Confidence intervals were calculated by the method of Cornfield. ${ }^{24}$

\section{Results}

ABORTION

Table 1 shows the $\mathrm{O} / \mathrm{E}$ ratios for abortion in current and previous pregnancies in managerial, clerical, and "other" sectors according to weekly hours of VDU use. In previous pregnancies, after correction for year of conception, the $\mathrm{O} / \mathrm{E}$ ratios varied little and showed no relation with the use of VDUs in any sector. In current pregnancies the $\mathrm{O} / \mathrm{E}$ ratio for those using
VDUs overall was significantly raised $(1 \cdot 19,90 \% \mathrm{CI}$ $1.09-1.30$ ). The $\mathrm{O} / \mathrm{E}$ ratio increased from 0.96 in nonusers $(90 \% \mathrm{CI} 0.92-1 \cdot 00)$ to $1 \cdot 14$ for use up to 15 hours a week $(90 \%$ CI $1.00-1.29)$ and to 1.23 for use 15 or more hours a week $(90 \%$ CI $1 \cdot 09-1 \cdot 38)$. This trend was statistically significant after accounting for possible confounding by sector $(p<0.01)$, a result largely determined by the pattern of risk in the clerical sector. There was no significant interaction between sector and the use of VDUs ( $p>0 \cdot 10)$ that is, the observed differences in trend between sectors could well be due to chance.

Table 2 summarises the results from the grouped analysis in current pregnancies. Occupations were classified into eight groups by the percentage of pregnancies in which a VDU was used for 15 or more hours a week, ranging from none to over $60 \%$; no trend was apparent in $\mathrm{O} / \mathrm{E}$ ratios. The estimated relative risk for the use of VDUs was $1.06(90 \% \mathrm{CI}$ $0 \cdot 8-1 \cdot 4)$. Table 3 shows detailed information for the five occupations with greatest use of VDUs; no increased risk was seen in any of the five. Results of a grouped analysis of previous pregnancies are not shown in detail but the pattern was similar-relative risk $1 \cdot 01(90 \%$ CI $0 \cdot 7-1 \cdot 3)$.

\section{STILLBIRTH}

No variation other than that attributable to chance was found in $\mathrm{O} / \mathrm{E}$ ratios in managerial, clerical, and remaining sectors in either current or previous preg-

Table 3 Ratios of observed $(O)$ to expected $(E)$ abortions in current pregnancies for the five occupations with the highest percentage use of a VDU for 15 or more hours a week

\begin{tabular}{|c|c|c|c|c|c|}
\hline \multirow[b]{2}{*}{ Occupation (CCO) } & \multirow{2}{*}{$\begin{array}{l}\text { No of } \\
\text { pregnancies }\end{array}$} & \multirow{2}{*}{$\begin{array}{l}\% \text { Use of } V D U \\
(\geqslant 15 \mathrm{~h} / \mathrm{wk})\end{array}$} & \multicolumn{2}{|c|}{ Abortions } & \multirow[b]{2}{*}{$(90 \% \mathrm{CI})$} \\
\hline & & & $O$ & $O / E$ & \\
\hline $\begin{array}{l}\text { Office machine and data processing operators (4141-3) } \\
\text { Mathematicians, statisticians, analysts (2181-9) } \\
\text { Typists and clerks in industry ( } 4113 \text {-industrial sectors } 1-47) \\
\text { Typists and clerks not in industry (4113-industrial sectors } 48-99) \\
\text { Cashiers and tellers (4133) }\end{array}$ & $\begin{array}{r}802 \\
269 \\
67 \\
288 \\
861\end{array}$ & $\begin{array}{l}63 \cdot 0 \\
56 \cdot 1 \\
53 \cdot 7 \\
31 \cdot 6 \\
31 \cdot 5\end{array}$ & $\begin{array}{r}57 \\
23 \\
4 \\
22 \\
57\end{array}$ & $\begin{array}{l}0.96 \\
1.08 \\
1.00 \\
0.96 \\
0.96\end{array}$ & $\begin{array}{l}(0 \cdot 76-1 \cdot 18) \\
(0 \cdot 74-1 \cdot 53) \\
(0 \cdot 34-2 \cdot 29) \\
(0 \cdot 69-1 \cdot 37) \\
(0 \cdot 76-1 \cdot 18)\end{array}$ \\
\hline
\end{tabular}


Table 4 Ratios of observed $(O)$ to expected $(E)$ preterm births ( $<37$ weeks) and low birthweight children by use of VDU in managerial, clerical, and remaining occupational sectors (current pregnancies)

\begin{tabular}{|c|c|c|c|c|c|c|c|}
\hline \multirow[b]{2}{*}{ Sectors } & \multirow[b]{2}{*}{ No } & \multicolumn{3}{|c|}{ Preterm births } & \multicolumn{3}{|c|}{ Low birth weight } \\
\hline & & $O$ & $O / E$ & $(90 \% C I)$ & $O$ & $O / E$ & $(90 \% C I)$ \\
\hline $\begin{array}{l}\text { Managerial-total: } \\
\text { VDU nil } \\
\text { VDU }<15 \mathrm{~h} / \mathrm{wk} \\
\text { VDU } \geqslant 15 \mathrm{~h} / \mathrm{wk}\end{array}$ & $\begin{array}{r}4213 \\
3399 \\
528 \\
286\end{array}$ & $\begin{array}{r}259 \\
204 \\
32 \\
23\end{array}$ & $\begin{array}{l}0.92 \\
0.90 \\
0.92 \\
1.19\end{array}$ & $\begin{array}{l}(0.83-1.01) \\
(0.80-1.00) \\
(0.67-1.21) \\
(0.81-1.68)\end{array}$ & $\begin{array}{r}205 \\
156 \\
29 \\
20\end{array}$ & $\begin{array}{l}0.89 \\
0.84 \\
0.98 \\
1.21\end{array}$ & $\begin{array}{l}(0.79-1.00) \\
(0.74-0.96) \\
(0.70-1.33) \\
(0.80-1.77)\end{array}$ \\
\hline $\begin{array}{l}\text { Clerical-total: } \\
\text { VDU nil } \\
\text { VDU <15 h/wk } \\
\text { VDU } \geqslant 15 \mathrm{~h} / \mathrm{wk}\end{array}$ & $\begin{array}{l}9868 \\
6656 \\
1542 \\
1670\end{array}$ & $\begin{array}{l}723 \\
475 \\
124 \\
124\end{array}$ & $\begin{array}{l}1.00 \\
0.97 \\
1 \cdot 12 \\
1.03\end{array}$ & $\begin{array}{l}(0.94-1.06) \\
(0.89-1.04) \\
(0.96-1.29) \\
(0.88-1.18)\end{array}$ & $\begin{array}{l}659 \\
444 \\
106 \\
109\end{array}$ & $\begin{array}{l}0.99 \\
0.99 \\
1.04 \\
0.97\end{array}$ & $\begin{array}{l}(0.93-1.06) \\
(0.91-1.07) \\
(0.88-1.22) \\
(0.83-1.13)\end{array}$ \\
\hline $\begin{array}{l}\text { Other-total: } \\
\text { VDU nil } \\
\text { VDU <15 h/wk } \\
\text { VDU } \geqslant 15 \mathrm{~h} / \mathrm{wk}\end{array}$ & $\begin{array}{r}8600 \\
8304 \\
157 \\
139\end{array}$ & $\begin{array}{r}701 \\
674 \\
15 \\
12\end{array}$ & $\begin{array}{l}1.03 \\
1.02 \\
1.39 \\
1.24\end{array}$ & $\begin{array}{l}(0.97-1 \cdot 10) \\
(0.96-1.09) \\
(0.86-2 \cdot 14) \\
(0.71-2 \cdot 01)\end{array}$ & $\begin{array}{r}637 \\
613 \\
11 \\
13\end{array}$ & $\begin{array}{l}1.05 \\
1.04 \\
1 \cdot 17 \\
1.44\end{array}$ & $\begin{array}{l}(0.98-1 \cdot 12) \\
(0.98-1 \cdot 12) \\
(0.66-1 \cdot 94) \\
(0.85-2 \cdot 29)\end{array}$ \\
\hline $\begin{array}{l}\text { All sectors-total: } \\
\text { VDU nil } \\
\text { VDU }<15 \mathrm{~h} / \mathrm{wk} \\
\text { VDU } \geqslant 15 \mathrm{~h} / \mathrm{wk}\end{array}$ & $\begin{array}{rl}22 & 681 \\
18 & 359 \\
2 & 227 \\
2 & 095\end{array}$ & $\begin{array}{r}1683 \\
1353 \\
171 \\
159\end{array}$ & $\begin{array}{l}1.00 \\
0.98 \\
1 \cdot 10 \\
1.06\end{array}$ & $\begin{array}{l}\overline{(0.94-1.02)} \\
(0.97-1.24) \\
(0.93-1.20)\end{array}$ & $\begin{array}{r}1501 \\
1213 \\
146 \\
142\end{array}$ & $\begin{array}{l}1.00 \\
0.99 \\
1.04 \\
1.03\end{array}$ & $\begin{array}{l}\overline{(0.95-1.04)} \\
(0.90-1 \cdot 19) \\
(0.89-1 \cdot 18)\end{array}$ \\
\hline
\end{tabular}

nancies. The $\mathrm{O} / \mathrm{E}$ ratios for all sectors combined in the three groups by hours of VDU use were for current pregnancies 1.04 (72 observed), 0.68 (five observed), and 0.95 (seven observed) and for previous pregnancies 1.03 (197 observed), 0.53 (five observed), and 0.89 (eight observed).

PREMATURITY

Table 4 shows the $\mathrm{O} / \mathrm{E}$ ratios for preterm births $(<37$ weeks) and low birth weight $(\leqslant 2500 \mathrm{~g})$. In the large clerical sector there was little variation with the use of
VDUs. In the managerial sector the $\mathrm{O} / \mathrm{E}$ ratios were raised for users of VDUs of 15 or more hours a week but not significantly so (preterm birth $\mathrm{O} / \mathrm{E}=1 \cdot 19$ (90\% CI 0.81-1.68) and low birth weight $1 \cdot 21(90 \% \mathrm{CI}$ $0.80-1.77)$. In the other sector the $\mathrm{O} / \mathrm{E}$ ratios for preterm births and low birth weight were again raised in users, but the numbers were small and for all ratios the $90 \%$ CI included unity. Poisson regression analyses showed no significant trend in risk of prematurity or low birth weight $(p>0 \cdot 10)$ after accounting for possible confounding by sector.

Table 5 Ratios of congenital defects observed $(O)$ to numbers expected $(E)$ in current and previous pregnancies of women who worked for at least 15 hours a week at the start of pregnancy

\begin{tabular}{|c|c|c|c|c|c|c|}
\hline \multirow[b]{2}{*}{ Congenital defect } & \multicolumn{3}{|l|}{ Current } & \multicolumn{3}{|l|}{ Previous } \\
\hline & $\begin{array}{l}V D U \text { not used } \\
O\end{array}$ & $\begin{array}{l}V D U \text { used } \\
O\end{array}$ & $\begin{array}{l}\text { Relative risk } \\
(90 \% \mathrm{CI})\end{array}$ & $\begin{array}{l}V D U \text { not used } \\
O\end{array}$ & $\begin{array}{l}V D U \text { used } \\
O\end{array}$ & $\begin{array}{l}\text { Relative risk } \\
(90 \% \text { CI) }\end{array}$ \\
\hline $\begin{array}{l}\text { Chromosomal } \\
\text { Developmental: }\end{array}$ & 39 & 7 & $0 \cdot 86(0.40-1 \cdot 78)$ & 39 & 1 & $0.27(0.05-1.43)$ \\
\hline $\begin{array}{l}\text { Neural tube defects } \\
\text { Cleft } \\
\text { Digestive respiratory } \\
\text { Cardiac } \\
\text { Renal urinary }\end{array}$ & $\begin{array}{l}55 \\
21 \\
38 \\
59 \\
39\end{array}$ & $\begin{array}{r}9 \\
6 \\
5 \\
16 \\
15\end{array}$ & $\begin{array}{l}0.78(0.40-1.47) \\
1.37(0.57-3.14) \\
0.63(0.25-1.46) \\
1.30(0.78-2.13) \\
1.84(1.07-3.15)\end{array}$ & $\begin{array}{l}49 \\
11 \\
25 \\
93 \\
51\end{array}$ & $\begin{array}{r}5 \\
2 \\
1 \\
10 \\
8\end{array}$ & $\begin{array}{l}1.08(0.43-2.47) \\
1.91(0.54-6.79) \\
0.42(0.08-2.25) \\
1.13(0.61-1.96) \\
1.66(0.82-3.25)\end{array}$ \\
\hline All & 212 & 51 & $1 \cdot 15(0 \cdot 88-1 \cdot 51)$ & 229 & 26 & $1.20(0.83-1.72)$ \\
\hline $\begin{array}{l}\text { Other: } \\
\text { Club foot } \\
\text { Other musculoskeletal } \\
\text { Hernias }\end{array}$ & $\begin{array}{r}172 \\
62 \\
39\end{array}$ & $\begin{array}{r}28 \\
11 \\
6\end{array}$ & $\begin{array}{l}0.78(0.54-1.11) \\
0.85(0.47-1.51) \\
0.74(0.32-1.60)\end{array}$ & $\begin{array}{r}130 \\
51 \\
68\end{array}$ & $\begin{array}{r}15 \\
5 \\
8\end{array}$ & $\begin{array}{l}1.21(0.74-1.95) \\
1.03(0.42-2.37) \\
1.24(0.62-2.40)\end{array}$ \\
\hline All & 273 & 45 & $0.79(0.60-1.04)$ & 249 & 28 & $1.19(0.84-1.68)$ \\
\hline Any defect & 524 & 103 & $0.94(0.78-1 \cdot 13)$ & 517 & 55 & $1.12(0.89-1.43)$ \\
\hline Total pregnancies & 22651 & 4731 & & 18514 & 1757 & \\
\hline
\end{tabular}


Table 6 Summary estimates of relative risk in users of VDUs for all adverse outcomes

\begin{tabular}{|c|c|c|c|c|}
\hline & \multicolumn{2}{|c|}{ Current } & \multicolumn{2}{|c|}{ Previous } \\
\hline & $O$ & Relative risk $(90 \% \mathrm{CI})$ & $O$ & Relative risk $(90 \% \mathrm{CI})$ \\
\hline $\begin{array}{l}\text { Spontaneous abortion: } \\
\text { Individual analysis* } \\
\text { Grouped analysis } \dagger \\
\text { Stillbirth** } \\
\text { Preterm** } \\
\text { Low birth weight* } \\
\text { Congenital defect } \ddagger\end{array}$ & $\begin{array}{r}361 \\
361 \\
12 \\
330 \\
228 \\
103\end{array}$ & $\begin{array}{l}1.19(1.09-1 \cdot 30) \\
1.06(0.8-1.4) \\
0.82(0.47-1.33) \\
1.08(0.98-1 \cdot 18) \\
1.03(0.92-1 \cdot 15) \\
0.94(0.78-1.13)\end{array}$ & $\begin{array}{r}415 \\
415 \\
13 \\
- \\
- \\
55\end{array}$ & $\begin{array}{l}0.97(0.89-1.05) \\
1.01(0.7-1.3) \\
0.71(0.42-1 \cdot 13) \\
1.12(0.89-1.43)\end{array}$ \\
\hline
\end{tabular}

* Risk relative to that in all working women $(\mathrm{O} / \mathrm{E}$ ratio).

+ Risk relative to working women not using VDUs (estimated from groups defined by occupation title).

†Risk relative to working women not using VDUs (odds ratios from two by two tables).

CONGENITAL DEFECT

Table 5 shows the relative risk for using VDUs in current and previous pregnancies for nine types of congenital defect grouped according to possible aetiology: chromosomal, developmental (potentially teratogenic), and other. The confidence intervals suggest that the variations in risk could generally be explained by chance. In the renal urinary group, however, the relative risk in current pregnancies was $1.84(\mathrm{p}=0.02$ in a one sided, corrected chi-squared test). The relative risk was also raised for this group in previous pregnancies $(1.64)$ but the numbers were small and the ratio did not approach significance.

\section{Discussion}

Scanty knowledge on the effects of employment on pregnant women prompted the large scale survey undertaken in Montreal. The disadvantage of our retrospective study design was the possibility of recall bias; on the other hand, it allowed detailed information to be collected on occupation and outcome in a large number of pregnancies. The main purpose of the survey was to examine occupational groups, chemical exposures, work requirements, and environmental conditions in relation to the four main adverse outcomes of pregnancy - spontaneous abortion, stillbirth, prematurity, and congenital defect. It was foreseen that the large body of data collected could also be used to test specific hypotheses.

With respect to the hypothesis that work with VDUs has an adverse effect in pregnancy, our survey has strength in numbers but susceptibility to recall bias. The interviews were conducted at a time when there was widespread public concern on the question and there was thus the possibility that both interviewer and subject might be influenced by the outcome of pregnancy when describing and recording the use of VDUs. The intermittent nature of using VDUs lends itself to error as the duration of exposure might be reported as net or gross, the latter including intervals when not at the instrument. There was evidence of this type of discrepancy in a follow up study of a sample of these workers. ${ }^{25}$ The six month difference between abortion and full term birth would also favour recall bias, as work at the beginning of pregnancy would be less well remembered by women at term than after miscarriage.

The findings for the use of VDUs and adverse outcome are summarised in table 6 . Only for spontaneous abortion in current pregnancies was there any evidence that the risk ratio was raised. Two points lead us to suspect that this finding may be due to recall bias. Firstly, the grouped analysis suggested that occupations with high VDU use did not have high risks for abortion; the RR for VDU use estimated by this method was $1 \cdot 06$, although with a wide confidence interval (0.8-1.4). Secondly, much of the evidence was obtained from the clerical sector where, despite frequent work with VDUs $(31 \%)$, the abortion risk was close to that for all working women $(1.01,90 \%$ CI $0.95-1.08$ ). The particularly depressed $\mathrm{O} / \mathrm{E}$ ratio in non-users in this sector and the increased ratio in users is compatible with overreporting of the use of VDUs after abortion and underreporting in term pregnancies.

The other finding of concern was the significantly raised risk of renal urinary defects. The excess in the users of VDUs was mainly attributable to hydronephrosis in current pregnancies (six cases observed, 2.59 expected) and to obstruction in the urinary tract or vesicoureteral reflux (six cases observed, 1.39 expected) in previous pregnancies. Although a causal relation cannot be dismissed, the nature of the abnormality and the absence of any obvious mechanism or prior evidence suggests that this may be a chance finding.

We acknowledge the invaluable cooperation of staff members in the 11 hospital maternity units (Charles Lemoyne, Jewish General, Laval, MaisonneuveRosemont, Notre-Dame, Sacré-Coeur, Ste-Justine, St-Luc, Royal Victoria, Ste-Mary's, St-Michel); we thank our nurses and clerks for their hard work and 
Drs C Commandeur, S Marquis, and I Tsarevsky for their many contributions.

\section{References}

1 Bergqvist U. Visual display terminals and health. Scand J Work Environ Health 1984;10 suppl 2:1-87.

2 Landrigan PJ, Melius JM, Rosenberg MJ, Caye MJ, Binkin NJ. Reproductive hazards in the workplace-development of epidemiologic research. Scand $J$ Work Environ Health 1983;33:83-8.

3 Purdham J. Adverse pregnancy outcome amongst VDT operators-the cluster phenomenon. Humane Technology 1984:27-40.

4 Bergqvist U. Pregnancy and VDT work - an evaluation of the state of the art. In: Proceedings of the international scientific conference on work with display units, Stockholm, 1986. Stockholm: Elsevier, 1987:678-82.

5 Butler DA. Do spontaneous abortion clusters among VDT operators signal a problem? In: Proceedings of the international scientific conference on work with display units, Stockholm, 1986. Stockholm: Elsevier, 1987:657-60.

6 National Institute for Occupational Safety and Health. A report on electromagnetic radiation surveys of video display terminals. Cincinnati: NIOSH, 1977. (DHEW (NIOSH) publ No 78-129, 1977.)

7 Michaelson SM. Health implications of exposure to radiofrequency/microwave energies. Br J Ind Med 1982;39:105-19.

8 Hansson-Mild K. Biological effects of low frequency electromagnetic fields. Humane Technology 1984:135-40.

9 Delgado JMR, Leal J, Monteagudo JL, Gracia MG. Embryological changes induced by weak, extremely low frequency electromagnetic fields. $J$ Anat 1982;134:533-51.

10 Sandstrom M, Hansson-Mild K, Lovtrup S. Effects of weak pulsed magnetic fields on chick embryogenesis. In: Proceedings of the international scientific conference on work with display units, Stockholm, May 1986. Stockholm: Elsevier, 1987:60-3.

11 Juutilainen J, Saali K. Effects of low frequency magnetic fields on the development of chick embryos. In: Proceedings of the international scientific conference on work with display units, Stockholm, May 1986. Stockholm: Elsevier, 1987:71-2.

12 Trubukait B, Cekan E, Paulsson LE. Effects of pulsed magnetic fields on embryonic development in mice. In: Proceedings of the international scientific conference on work with display units, Stockholm, May 1986. Stockholm: Elsevier, 1987:68-70.

13 Kurppa K, Holmberg PC, Rantala K, Nurminen T, Saxen L. Birth defects and exposure to video display terminals during pregnancy. A Finnish case-referent study. Scand $J$ Work Environ Health 1985;11:353-6.

14 Butler WJ, Brix KA. Video display terminal work and pregnancy outcome in Michigan clerical workers. Humane Technology 1986:67-91.

15 Westerholm P, Ericson A. Pregnancy outcome and VDU work in a cohort of insurance clerks. In: Knave B, Wideback PG, eds. Work with display units. Stockholm: Elsevier, 1987:104-10.

16 McDonald AD, McDonald JC, Armstrong B, et al. Occupation and pregnancy outcome. $\mathrm{Br}$ J Ind Med 1987;44:521-6.

17 McDonald AD, McDonald JC, Armstrong B, et al. Fetal death and work in pregnancy. Br J Ind Med 1988;45:148-57.

$18 \mathrm{McDonald}$ AD, McDonald JC, Armstrong B, et al. Congenital defects and work in pregnancy. $\mathrm{Br} J$ Ind Med (in press).

19 McDonald AD, McDonald JC, Armstrong B, Cherry NM, DNolin A, Robert D. Prematurity and work in pregnancy. $B r J$ Ind Med 1988;45:56-62.

20 McDonald A. Birth defect, spontaneous abortion and work with VDUs. In: Knave B, Wideback PG, eds. Work with display units. Stockholm: Elsevier, 1986:94-5.

21 McDonald AD, Cherry NM, Delorme C, McDonald JC. Visual display units and pregnancy: evidence from the Montreal survey. J Occup Med 1986;28:1226-31.

22 Baker RJ, Nelder JA. The GLIM system: release 3. Oxford: Numerical Algorithms Group, 1978.

23 Morgenstern $H$. Uses of ecologic analysis in epidemiological research. Am J Public Health 1982;72:1336-44.

24 Cornfield J. A statistical problem arising from retrospective studies. In: Neyman J, ed. Proceedings of the third Berkeley symposium, IV. Berkeley: University of California 1987:133-48.

25 Cherry N. Physical demands of work and health complaints among women working late in pregnancy. Ergonomics 1987;30:689-701. 